\title{
Peran Tata Kelola Perusahaan Dalam Kinerja Operasional dan Kinerja Pasar Di Indonesia
}

\author{
Novi Damayanti ${ }^{1}$ dan Amrie Firmansyah ${ }^{2}$ \\ ${ }^{1,2}$ Jurusan Akuntansi, Politeknik Keuangan Negara STAN \\ Email Address: \\ novi.ac28@gmail.com, amrie@pknstan.ac.id
}

\begin{abstract}
This study investigates the association's corporate governance and the company's operational performance and market performance. The research data is sourced from financial reports and annual reports of consumer goods sector companies listed on the Indonesia Stock Exchange from 2015 to 2019, obtained from www.idx.co.id. Based on purposive sampling, the total sample in this study amounted to 120 observations. Hypothesis testing in this study uses multiple regression analysis for panel data. This study suggests that corporate governance is negatively associated with a company's operational performance but is not associated with the company's market performance. However, the implementation of governance in Indonesia is still administrative and has not been implemented by companies properly. This research indicates that the Financial Services Authority needs to improve policies and monitor issuers related to governance implementation.
\end{abstract}

Keywords: Governance, Performance, Company Operations, Market Response.

\begin{abstract}
Abstrak: Penelitian ini bertujuan untuk menginvestigasi hubungan tata kelola perusahaan dan kinerja operasional serta kinerja pasar perusahaan. Data penelitian bersumber dari laporan keuangan dan laporan tahunan perusahaan sektor barang konsumsi yang terdaftar di Bursa Efek Indonesia tahun 2015 sampai dengan tahun 2019 yang diperoleh dari www.idx.co.id. Berdasarkan purposive sampling, total sampel dalam penelitian ini berjumlah 120 observasi. Pengujian hipotesis dalam penelitian ini menggunakan analisis regresi berganda untuk data panel. Penelitian ini menyimpulkan bahwa tata kelola perusahaan berpengaruh negatif terhadap kinerja operasional perusahaan, namun tidak berpengaruh terhadap kinerja pasar perusahaan. Penerapan tata kelola di Indonesia masih bersifat administratif, dan belum diimplementasikan oleh perusahaan dengan baik. Penelitian ini mengindikasikan bahwa Otoritas Jasa Keuangan perlu untuk meningkatkan kebijakan dan monitoring kepada emiten terkait dengan implementasi tata kelola.
\end{abstract}

Kata Kunci: Tata Kelola, Kinerja, Operasi Perusahaan, Respon Pasar.

\section{PENDAHULUAN}

Investor mengharapkan untuk mendapatkan tingkat pengembalian yang tinggi dimasa mendatang (Ferdiani, 2019). Untuk menarik minat para investor, salah satu 
indikator pertimbangan investor dalam berinvestasi adalah kinerja perusahaan. Kinerja perusahaan adalah indikator bahwa perusahaan telah mencapai tujuannya secara efektif dan efisien (Naufal, 2018). Peningkatan kinerja perusahaan berarti meningkat pula mutu dan kualitas perusahaan itu sendiri. Indikator dari tercapainya kinerja yang baik adalah kinerja operasional dan kinerja pasar. Kinerja operasional merupakan ukuran bagaimana cara suatu perusahaan menghasilkan laba serta mengelola asetnya (Anggraini, 2010). Indikator lain dari tercapainya kinerja suatu perusahaan selanjutnya adalah kinerja pasar. Kinerja pasar merupakan capaian perusahaan dalam meningkatkan nilai saham di pasar modal (Setiawan, 2017). Nilai saham perusahaan dalam pasar modal merupakan cerminan dari kinerja perusahaan yang dapat meningkatkan minat serta kepercayaan investor.

Dalam mengukur kinerja suatu perusahaan, investor diharapkan dapat menggunakan laporan keuangan sebagai dasar penilaian terhadap keuangan perusahaan. Perusahaan yang berkinerja baik mendorong investor untuk memberikan sumber daya yang dimilikinya kepada perusahaan dalam bentuk investasi saham (Dzahabiyya et al., 2020). Kinerja perusahaan merupakan pencapaian perusahaan dalam memenuhi sasaran yang telah ditetapkan sebelumnya (Febrianto, 2016). Pencapaian tersebut adalah hasil kinerja manajer dalam mengelola sumber daya yang ada untuk menghasilkan laba yang sebesar-besarnya. Laba yang tinggi akan meningkatkan kesejahteraan investor sebagai hasil dari modal yang ditanamkan pada perusahaan (Sintyana dan Artini, 2019). Berdasarkan hal tersebut, terdapat dua pihak yang berperan penting dalam menjalankan perusahaan yaitu manajer dan pemilik modal. Manajer sebagai pihak yang diberikan wewenang oleh investor untuk mengelola sumber daya yang ada pada perusahaan, sedangkan investor menyediakan modalnya untuk dijadikan sumber daya dalam menjalankan perusahaan. Pemilik memberikan wewenang kepada manajer dengan harapan agar perusahaan mampu menghasilkan profit yang akan menambah kesejahteraan pemilik modal.

Sebagai pihak yang menjalankan perusahaan, manajer memiliki informasi yang lebih sempurna dibandingkan dengan pemegang saham. Dalam mengelola sumber daya yang ada, manajer berkewajiban menyampaikan kondisi perusahaan kepada pemilik modal (Lisa, 2012). Namun, informasi yang disampaikan tidak selamanya berdasarkan kondisi perusahaan sesungguhnya. Adanya perbedaan kepentingan tersebut memicu konflik antara manajer dengan pemilik modal, karena manajer tidak selalu menyelaraskan kepentingannya dengan kepentingan pemilik perusahaan (Jensen dan Meckling, 1976). Manajer cenderung untuk memfokuskan pada proyek yang mampu menghasilkan keuntungan dalam jangka pendek dibandingkan keuntungan pada proyek jangka panjang (Wiyarsi, 2012). Terdapat dua indikator yang menunjukkan keberhasilan suatu perusahaan yaitu kinerja operasional dan kinerja pasar (Al-Matari et al., 2014). Kinerja operasional merupakan kemampuan perusahaan dalam menggunakan sumber daya perusahaan dalam mencapai tujuannya secara efektif (Ibrahim, 2016). Kinerja operasional yang baik akan menghasilkan laba yang tinggi (Ibrahim, 2016). Selain itu, kinerja pasar terkait kemampuan manajer dalam meningkatkan harga saham perusahaan di pasar modal. Kinerja pasar yang baik akan mendorong investor untuk menanamkan modalnya kepada perusahaan yang, sehingga berdampak pada semakin tingginya harga saham.

Optimalisasi kinerja perusahaan, baik kinerja operasional maupun kinerja pasar, menjadi hal yang penting bagi berbagai pihak terutama investor. Kesuksesan perusahaaan dalam mengelola aset yang ada serta menghasilkan laba merupakan hasil kinerja 
operasional yang baik. Kinerja perusahaan yang tinggi mendorong investor memberikan respon positif (Lukman, 2014). Sebaliknya, ketidakmampuan perusahaan dalam mengelola aset perusahaan serta menghasilkan profit merupakan informasi buruk bagi para investor (Salim dan Simatupang, 2016). Kondisi ini akan menurunkan minat investor menanamkan modalnya kepada perusahaan tersebut. Terkait dengan hal tersebut, investor membutuhkan informasi kinerja operasional dan kinerja pasar sebagai daasar analisis dalam pengambilan keputusan investasi. Oleh karena itu, ulasan mengenai kinerja operasional dan kinerja pasar perlu dilakukan investigasi lebih lanjut.

Penelitian mengenai kinerja perusahaan telah dibahas oleh beberapa peneliti terdahulu. Pengujian kinerja operasional telah dilakukan dengan beberapa faktor seperti dewan komisaris independen (Fadillah, 2017; Dewi et al., 2018; Veno, 2015; Situmorang dan Simanjuntak, 2019), kepemilikan manajerial (Fadillah, 2017; Masitoh dan Hidayah, 2018), dan kepemilikan institusional (Fadillah, 2017; Situmorang dan Simanjuntak, 2019), kepemilikan publik (Masitoh dan Hidayah, 2018), dewan komisaris (Veno, 2015; Putri dan Muid, 2017), proporsi dewan komisaris (Putri dan Muid, 2017), frekuensi rapat dewan komisaris (Putri dan Muid, 2017), dewan direksi (Veno, 2105; Masitoh dan Hidayah, 2018; Situmorang dan Simanjuntak, 2019), proporsi dewan direksi independen (Masitoh dan Hidayah, 2018), komite audit (Veno, 2015), intellectual capital (Lestari, 2017), dan Indeks tata kelola SWA (Hediono dan Prasetyaningsih). Penelitan yang mengukur kinerja pasar perusahaan antara lain diuji dengan tax avoidance (Irawan dan Turwanto, 2020), leverage (Ahmad et al., 2018; Hidayat, 2018; Kholis et al., 2018; Lubis et al., 2018; Suroto, 2018), dividends (Suroto, 2018; Ahmad et al., 2018), CSR Disclosures (Putri et al., 2020; Firmansyah dan Ardi, 2020; Karina dan Setiadi, 2020), Liquidity (Ahmad et al., 2018; Lubis et al., 2018), kualitas laba (Oktavia, 2011; Rahayu dan Sari, 2018), instrumen derivatif (Firmansyah dan Purnama, 2020; Novianti dan Firmansyah), tax risk (Novianti dan Firmansyah, 2020), komite audit (Syafitri et al., 2018; Sarafina dan Saifi, 2017; Susilo dan Fuad, 2018), kepemilikan manajerial (Syafitri et al., 2018; Susilo dan Fuad, 2018), dewan direksi (Syafitri et al, 2018), dewan komisaris (Syafitri et al., 2018; Susilo dan Fuad, 2018), dewan komisaris independen (Sarafina dan Saifi, 2017), kepemilikan institusional (Susilo dan Fuad, 2018), dan Indeks tata kelola SWA (Hediono dan Prasetyaningsih).

Manajemen merupakan wakil pemegang saham untuk dapat bekerja sesuai dengan kepentingan pemegang saham (Ichsan, 2013). Namun, adanya pemisahaan wewenang antara pemegang saham dan manajemen menimbulkan adanya perbedaan kepentingan. Untuk meminimalisasi perbedaan tersebut perlu diterapkan tata kelola perusahaan yang baik (Haryono dan Paminto, 2015). Kinerja operasional dan kinerja pasar merupakan perwujudan tugas manajer dalam menjalankan perusahaan. Manajer memiliki informasi yang lebih sempurna terkait dengan kondisi perusahaan dibandingkan dengan pemilik perusahaan. Adanya informasi asimetri mengakibatkan transparansi yang menjadi salah satu unsur tata kelola menjadi penting untuk diimplementasikan dengan baik.

Pada tahun 2001 di Amerika Serikat, sejarah mencatat adanya praktik kecurangan yang cukup menggemparkan dunia. Kasus enron yang merupakan penipuan akuntansi yang terlembaga, sistematis, dan terencana secara kreatif (http://kumpulanstudiaspirasi.com). Kasus tersebut didorong akibat perilaku moral hazard untuk melakukan manipulasi laporan keuangan agar saham tetap diminati investor dan memenuhi harapan 
investor (Hadiyanti, 2013). Kasus tersebut merupakan salah satu kasus yang melatarbelakangi lahirnya pengungkapan tata kelola perusahaan di Amerika Serikat sebagai bentuk pertanggungjawaban perusahaan publik kepada stakeholdernya. Kasus tersebut merupakan contoh dari tata kelola perusahaan yang buruk. Kondisi ini mengakibatkan berkurangnya kepercayaan masyarakat dan menurunkan minat masyarakat untuk berinvestasi pada perusahaan tersebut. Konsep pengungkapan tata kelola perusahaan bertujuan agar manajemen menyeleraskan kepentingannya dengan kepentingan pemegang saham (Sianggono dan Mustamu, 2018). Penerapan tata kelola perusahan yang baik diharapkan dapat meningkatkan kepercayaan para pemegang saham, investor, dan stakeholder lainnya.

Beberapa penelitian telah menguji komponen tata kelola perusahaan terhadap kinerja operasional dan kinerja pasar perusahaan. (Tertius dan Christiawan, 2015) menemukan bahwa kepemilikan manajerial dan dewan komisaris tidak berhubungan dengan kinerja perusahaan, sedangkan komisaris independen menurunkan kinerja perusahaan. Sementara itu, (Veno, 2015) membuktikan bahwa komite audit dan dewan direksi berpengaruh positif dapat meningkatkan kinerja perusahaan, sedangkan dewan komisaris independen menurunkan kinerja perusahaan. Penelitian lainnya menguji pengaruh penerapan pengungkapan tata kelola perusahaan terhadap kinerja pasar. (Sarafina dan Saifi, 2017) menemukan bahwa komite audit dan dewan komisaris berpengaruh positif terhadap kinerja keuangan maupun nilai perusahaan. (Susilo dan Fuad, 2018) menyimpulkan bahwa komite audit, komisaris independen, dan kepemilikan institusional berpengaruh positif terhadap kinerja keuangan. Namun, penelitian tersebut tidak menemukan bahwa kepemilikan manajerial memiliki pengaruh terhadap kinerja keuangan. Selain itu, (Syafitri et al., 2018) menyimpulkan bahwa komite audit, dewan direksi, dan total dewan komisaris dapat meningkatkan kinerja pasar, sedangkan kepemilikan manajerial tidak memiliki hubungan dengan kinerja pasar. Adanya inkonsistensi hasil pengujian tersebut mengakibatkan perlunya kembali menguji tata kelola perusahaan terhadap kinerja operasioanl dan kinerja pasar.

Penelitian ini bertujuan untuk menginvestigasi pengaruh pengungkapan tata kelola perusahaan. Penelitian sebelumnya menggunakan tata kelola perusahaan dengan berbagai komponen seperti komite audit, dewan direksi, dewan komisaris, kepemilikan manajerial dan institusional (Syafitri et al., 2018; Sarafina dan Saifi, 2017; Veno, 2015; Susilo dan Fuad, 2018, Putri dan Muid, 2017; Masitoh dan Hidayah, 2018; Tertius dan Christiawan, 2015), karakteristik dewan komisaris (Dewi et al., 2018), indeks tata kelola perusahaan (Hediono dan Prasetyaningsih, 2019). (Syafitri et al.. 2018) dan (Sarafina dan Saifi, 2017) menggunakan mekanisme tata kelola perusahaan yang terdiri atas komite audit, dewan direksi, dewan komisaris, kepemilikan manajerial dan institusional. (Hediono dan Prasetyaningsih, 2019) menggunakan indeks pengungkapan tata kelola perusahaan berdasarkan pada hasil survey tentang pemeringkatan perusahaan yang dilakukan oleh IICG melalui kerjasama dengan majalah SWA pada perusahaan publik di Indonesia.

Penelitian ini menggunakan pengungkapan tata kelola perusahaan sesuai dengan indeks yang digunakan oleh (Firmansyah et al., 2021) berdasarkan pada SE OJK No. 32/SEOJK.04/2015 yang berbeda dengan beberapa penelitian sebelumnya. Penggunaan indeks yang dikembangkan oleh OJK pada penelitian ini dianggap lebih relevan dengan pengungkapan tata kelola perusahaan pada kondisi saat ini (Putri et al., 2020). Pedoman 
tata kelola perusahaan yang dikembangkan oleh OJK dianggap lebih relevan dibandingkan dengan indeks sebelumnya karena dikembangkan sesuai dengan kondisi perusahaan di Indonesia. Indeks tata kelola perusahaan yang dikembangkan oleh OJK telah digunakan oleh (Firmansyah et al., 2021) dan (Putri et al., 2021). Namun, (Firmansyah et al., 2021) dan (Putri et al., 2020) hanya menguji tata kelola perusahaan terhadap kinerja pasar, sementara penelitian ini juga menguji tata kelola perusahaan terhadap kinerja operasional perusahaan. Penggunaan indeks tata kelola perusahaan berdasakan SE OJK masih jarang digunakan untuk mengukur kinerja operasional perusahaan pada penelitian-penelitian sebelumnya.

Penelitian ini diharapkan memiliki kontribusi dalam melengkapi atau menambah literatur terkait dengan pentingnya penerapan pengungkapan tata kelola perusahaan di Indonesia sebagai prinsip yang berguna untuk menunjang kemajuan perusahaan, terutama pengaruhnya terhadap kinerja operasional dan kinerja pasar. Selain itu, hasil penelitian ini diharapkan dapat berguna bagi manajemen perusahaan untuk memperbaiki kinerja perusahaan di masa mendatang, dan bagi investor dalam pengambilan keputusan investasi di pasar modal, sedangkan bagi OJK untuk memperbaiki kebijakan penerapan tata kelola perusahaan dalam rangka perlindungan investor di pasar modal Indonesia. Penelitian ini menggunakan data perusahaan sektor industri barang konsumsi karena barang industri konsumsi dinilai cukup bertahan ditengah pandemi covid-19 saat ini (Suryahadi, 2020). Berdasarkan indeks barang konsumsi, indeks sektor barang konsumsi hanya terkoreksi 5,5\% dibandingkan dengan IHSG yang terkoreksi sebesar 18,6\% (Suryahadi, 2020).

\section{KAJIAN TEORI}

Teori Keagenan. Hubungan keagenan didefiniskan sebagai kontrak dimana suatu pihak (pemilik) menunjuk pihak lainnya (agen pengurus atau manajemen) untuk melakukan pekerjaan atas nama pemilik (Veno, 2015). Penunjukkan tersebut termasuk pemberian wewenang dalam hal pengambilan keputusan dalam mengelola kekayaan pemilik. Pemilik memiliki harapan bahwa pendelegasian pengelolaan tersebut dapat meningkatkan kekayaan dan kemakmuran pemilik (Darwis, 2012). Manajemen diharapkan mampu mengelola sumber yang ada secara maksimal.

Manajer sebagai pengelola perusahaan, memiliki informasi internal yang lebih banyak dibandingkan dengan pemilik perusahaan (Jensen dan Meckling, 1976). Para manajer memiliki kontak langsung dalam pengelolaan perusahaan sehingga mengetahui peristiwa-peristiwa yang terjadi dalam lingkungan internal (Lisa, 2012). Kondisi ini mengakibatkan manajer bertindak untuk kepentingan dirinya. Selain itu, keterbatasan para pemilik saham dalam mengawasi aktivitas yang dilakukan manajer, yang dapat memberikan kesempatan kepada manajer untuk melakukan tindakan yang tidak selaras dengan kepentingan pemilik (Jensen dan Meckling, 1976).

Hubungan keagenan tersebut dapat menimbulkan suatu masalah apabila kedua belah pihak memiliki tujuan yang berbeda. Apabila kedua belah pihak memaksimalkan perannya, terdapat kemungkinan bahwa manajemen tidak bertindak untuk kepentingan pemilik. Setiap pihak akan berusaha memaksimalkan nilai kepuasannya masing-masing atau sering disebut dengan fungsi utilitas (Jensen dan Meckling, 1976). (Veno, 2015) menyebutkan bahwa pada umumnya pemilik memiliki harapan untuk perusahaan dapat 
beroperasi terus-menerus, sedangkan manajemen lebih cenderung menginginkan untuk mendapatkan laba dalam jangka pendek. Kecenderungan tersebut menyebabkan manajemen mengabaikan keberlanjutan perusahaan dalam jangka panjang.

Adanya masalah keagenan tersebut dapat menimbulkan konflik pada perusahaan. Prinsipal hanya tertarik pada pengembalian investasi dari modal yang diinvestasikan, sedangkan agen akan puas untuk mendapatkan kompensasi finansial sesuai dengan konrak yang telah dibuat. Akibat adanya konflik kepentingan, hubungan sinergi antara keduanya sulit untuk tercipta. (Aziz dan Hartono, 2017). Manajer memiliki informasi yang lebih banyak dibandingkan dengan para pemilik. Manajer sebagai agen akan mengungkapkan informasi perusahaan yang menguntungkan bagi kepentingannya sendiri. Berdasarkan teori kegaenan, manager tentunya akan mengambil keputusan yang akan memaksimalkan labanya untuk menaikkan bonus untuk diri mereka. Sebaliknya, manajer tidak akan bertindak secara optimal dalam mengelola kekayaan pemilik apabila tidak mendapatkan keuntungan yang maksimal. Kurangnya pengawasan terhadap kinerja manajer menyebabkan keputusan manajer kurang sesuai dengan keinginan pemilik. Kondisi tersebut dapat memicu terjadinya kecurangan dan penipuan. Pengungkapan informasi yang dilakukan manajer melalui laporan keuangan dapat dimanipulasi demi menunjukkan kinerja baik dari manajer. Selain itu, kecenderungan manajer dalam mengambil keputusan dengan tujuan untuk kepentingan sendiri dapat menurunkan kepercayaan investor. Kurangnya transparansi dalam pengungkapan tata kelola perusahaan juga menurunkan minat investor dalam menanamkan modalnya.

Pengembangan Hipotesis. Menurut teori keagenan, adanya perbedaan kepentingan manajer dan pemegang saham mengakibatkan asimetri informasi di antara keduanya, di mana manajer dalam perusahaan memiliki informasi yang lebih sempurna daripada pemegang saham (Aziz dan Hartono, 2017). Situasi ini memberi manajer kesempatan untuk memaksimalkan kepentingan pribadi mereka. Salah satu cara untuk meminimalisir adanya benturan kepentingan tersebut yaitu melai penerapan prinsip-prinsip pengungkapan tata kelola perusahaan (Kaban et al., 2017). Tata kelola perusahaan mendorong untuk memastikan kepada para pemegang saham bahwa sumber daya yang diberikan kepada perusahaan dapat digunakan secara tepat dan efisien (Dwiriditjahyono, 2010). Selain itu, melalui pengungkapan tata kelola perusahaan, perusahaan meyakinkan pihak internal bahwa manajer akan melakukan tindakan yang terbaik demi kepentingan perusahaan (Mujiati, 2016).

Perusahaan yang menerapkan prinsip tersebut akan mengelola bisnis secara bertanggungjawab dan transparan. (Hediono dan Prasetyaningsih, 2019) menyimpulkan bahwa penerapan tata kelola perusahaan berpengaruh secara positif terhadap kinerja perusahaan. Kondisi ini ditunjukkan pada rata-rata laba bersih pada perusahaan yang menjadi sampel lebih tinggi dari pada laba operasional. Rata-rata perusahaan memperoleh pendapatan non operaional yang cukup tinggi. Selain itu, (Putri dan Mudi, 2017) menyatakan bahwa penerapan pengungkapan tata kelola perusahaan yang diproksikan pada jumlah anggota dewan komisaris dan frekuensi rapat dewan komisaris berpengaruh terhadap kinerja perusahaan. Penelitian tersebut menyatakan bahwa semakin besar jumlah anggota dewan komisaris maka kinerja operasional perusahaan menjadi meningkat. Selain itu, tingginya frekuensi rapat dewan komisaris menghasilkan keputusan yang semakin 
baik sehingga berdampak positif pada kinerja perusahaan. Hasil yang serupa ditemukan oleh (Veno, 2015) bahwa mekanisme pemantauan pengendalian internal akan mendorong manajer untuk meningkatkan kinerja perusahaan. Pengendalian internal dilakukan melalui pengendalian dalam diri manajer melalui perhatian pemilik terhadap kepentingan manager dan melalui pihak lain agar manager dapat meningkatkan efisiensi.

Penerapan pengungkapan tata kelola perusahaan akan meningkatkan kinerja operasional perusahaan menjadi lebih efisien. Teori agensi menyatakan bahwa pemilik sebaiknya menyerahkan pengelolaan perusahaan kepada agen yang lebih baik dalam mengelola modalnya, sedangkan agen bertugas untuk menjalankan perusahaan demi memaksimalkan kepentingan pemilik. Prinsip pengungkapan tata kelola perusahaan memberikan jaminan bahwa manajemen bertindak demi kepentingan pemegang saham. Para agen dituntut untuk bekerja sesuai dengan fungsi dan tanggungjawabnya melalui pengawasan terhadap kinerja manajer. Kinerja perusahaan yang baik akan meningkatkan profit perusahaaan sehingga kepastian perusahaan di masa depan semakin tinggi.

H1: Pengungkapan tata kelola perusahaan berpengaruh positif terhadap kinerja operasional.

Teori agensi menjelaskan hubungan antara pemilik dengan manajer. Hubungan tersebut memungkinkan terjadinya benturan kepentingan dari masing-masing pihak (Akana, 2017). Prinsip tata kelola perusahaan dapat mengurangi risiko adanya konflik kepentingan sehingga terdapat kepercayaan investor untuk menanamkan modalnya. Prinsip pengungkapan tata kelola perusahaan memastikan bahwa manajer bertindak sesuai dengan kepentingan pemegan saham. (Veno, 2015) menemukan bahwa pengungkapan tata kelola perusahaan meningkatkan kinerja operasional perusahaan. Peningkatan kinerja operasional perusahaan erat kaitannya dengan peningkatan harga saham (Pratiwi, 2019). Harga saham di pasar modal menunjukkan kinerja perusahaan yang direspon oleh investor. Harga saham yang tinggi mengindikasikan baiknya kinerja pasar perusahaan tersebut baik (Natalia et al., 2016).

Penerapan pengungkapan tata kelola perusahaan memiliki pengaruh baik bukan hanya terhadap kinerja keuangan tetapi juga terhadap kinerja pasar (Sarafina et al., 2017). Penerapan tata kelola perusahaan akan mendorong masing-masing pihak bekerjasama dalam mencapai target perusahaan secara optimal. Pencapaian target perusahaan akan menyebabkan kinerja operasional menjadi semakin baik sehingga berdampak pada return yang baik pula. Tingkat return yang tinggi akan menyebabkan kepuasan dan kepercayaan pada pemegang saham yang akan berdampak pada kinerja pasar. Menurut (Syafitri et al., 2018) prinsip pengungkapan tata kelola perusahaan diperlukan dalam meningkatkan keberhasilan dan nilai perusahaan di mata publik. (Suharyati, 2019) menyatakan bahwa investor perlu memperhatikan informasi pengungkapan tata kelola perusahaan yang diberikan perusahaan kepada publik.

Berdasarkan penelitan-penelitian tersebut, perusahaan yang menerapkan prinsip pengungkapan tata kelola perusahaan akan memberikan respon positif dari para investor. Prinsip tata kelola perusahaan diharapkan mampu meminimalkan konflik yang terjadi akibat dari adanya informasi asimetri yang ada antara agen dan pemilik. Penerapan 
pengungkapan tata kelola perusahaan dapat membuat hubungan yang baik antara manajer dengan pemilik modal sehingga tercipta atmosfir bisnis yang sehat dan menguntungkan.

H2: Pengungkapan tata kelola perusahaan memiliki pengaruh terhadap kinerja pasar.

\section{METODOLOGI}

Data penelitian ini bersumber dari laporan keuangan dan laporan tahunan perusahaan tahun 2015 sampai dengan tahun 2019 yang diperoleh dari www.idx.co.id. Sampel penelitian ini adalah perusahaan sektor industri barang konsumsi yang terdaftar di BEI. Tabel 1 merupakan ringkasan kriteria sampel berdasarkan purposive sampling.

Tabel 1. Sampel Penelitian

\begin{tabular}{lcc}
\hline \multicolumn{1}{c}{ Kriteria } & Jumlah & Ukuran \\
\hline Perusahaan sektor barang konsumsi Februari 2021 & 65 & Perusahaan \\
Perusahaan yang terdaftar di BEI setelah 1 Januari 2016 & $(24)$ & Perusahaan \\
Perusahaan yang tidak memiliki data secara lengkap lengkap & $(11)$ & Perusahaan \\
Jumlah perusahaan yang dapat digunakan dalam penelitian & 30 & Perusahaan \\
Jumlah tahun observasi & 4 & Perusahaan \\
Total sampel & 120 & Observasi \\
\hline
\end{tabular}

Sumber: diolah

Kinerja operasional dan kinerja pasar digunakan sebagai variabel dependen, sedangkan pengungkapan tata kelola perusahaan adalah variabel independen. Selain itu, penelitian ini menggunakan ukuran perusahaan, profitabilitas dan leverage sebagai variabel kontrol. Kinerja operasional diukur menggunakan proksi return on equity (ROE) yang mengacu pada penelitian oleh (Veno, 2015). Tingkat pengembalian ekuitas menjadi ukuran profitabilitas bagi para pemilik modal sehingga memilik arti penting dalam mengukur kinerja perusahaan.

$$
R O E=\frac{\text { Laba bersih }}{\text { Modal Sendiri }} \times 100 \%
$$

Kinerja pasar menggunakan proksi rasio tobin's Q sebagaimana (Dzahabiyya et al., 2020), (Firmansyah et al., 2021), dan (Firmansyah dan Purnama, 2021). Rasio tobins'Q diukur dengan cara membagi jumlah nilai pasar ekuitas (market value equity) ditambah liabilitas perusahaan dengan total aset yang ada. Adapun formula untuk menghitung rasio tobin's Q suatu perusahaan adalah sebagai berikut :

$$
\text { Tobins }^{\prime} Q=\frac{M V E+\text { Debt }}{\text { Total Asset }}
$$

Pengungkapan tata kelola perusahaan diukur dengan indeks SE-OJK nomor 32 tahun 2015 sebagaimana (Putri et al., 2020) dan (Firmansyah et al., 2021). Indeks pengungkapan tata kelola perusahaan tersebut sejalan dengan indeks tata kelola 
berdasarkan OECD yang dilakukan oleh (Saksessia dan Firmansyah, 2020). Indeks dalam penelitian ini menggunakan 25 item. Pemberian skor dilakukan dengan memberikan nilai 1 untuk perusahaan yang menerapkan salah satu rekomendasi yang telah ditetapkan oleh OJK dan memberikan nilai 0 untuk perusahaan yang belum menerapkan rekomendasi tersebut. Data terkait penerapan rekomendasi tata kelola perusahaan oleh perusahaan didapatkan dari laporan tahunan perusahaan. Adapun formula untuk mengukur prinsip tata kelola perusahaan adalah sebagai berikut :

$$
G C G=\frac{\text { Jumlah nilai tata kelola perusahaan yang diterapkan }}{\text { Jumlah kriteria penerapan GCG }}
$$

Ukuran perusahaan dinyatakan dengan jumlah aktiva secara keseluruhan milik perusahaan (Rudangga dan Sudiarta, 2016). Ukuran perusahaan atau firm size dikalkukasi dengan menggunakan bentuk logaritma natural dari total aset. Pengukuran menggunakan logaritma natural dari total aset perusahaan bertujuan untuk mengurangi fluktuasi data yang berlebih (Maretha, 2016). Hal ini akan menyederhanakan nilai aset yang mempunyai nilai ratusan miliar tanpa mngubah proporsi jumlah aset sebenarnya. Adapun formula untuk menghitung ukuran perusahaan yaitu :

$$
\text { Ukuran perusahaan }=\operatorname{Ln}(\text { Total aset })
$$

(Sartono, 2012) menyebutkan bahwa financial leverage mengindikasikan rasio atas penggunaan utang dalam membiayai investasi suatu perusahaan. perusahaan yang nilai leverage nya 0 berarti perusahaan tersebut dibiayai dengan modal sendiri secara keseluruhan. Terdapat beberapa rasio untuk mengukur nilai leverage salah satunya adalah debt ratio. Penggunaan proksi debt ratio sebagai ukuran leverage mengikuti (Sambora et al.. 2014) dan (Siregar, 2016). Adapun formula untuk menghitung nilai debt ratio yaitu :

$$
\text { Debt Ratio }=\frac{\text { Total utang }}{\text { Total Aset }}
$$

Profitabilitas menggunakan proksi net profit margin sebagaimana (Lestari et al., 2018), (Sambelay et al., 2017), (Effendi dan Hermanto, 2017). Adapun formula untuk menghitung nilai net profit margin yaitu:

$$
N P M=\frac{\text { Laba bersih }}{\text { Penjualan bersih }}
$$

Selanjutnya, uji analisis data penelitian ini menggunakan analisis regresi untuk data panel. Penelitian ini menggunakan dua model. Model yang pertama menguji pengaruh pengungkapan tata kelola perusahaan terhadap kinerja operasional. Berikut model regresi pertama dalam penelitian ini :

ROEit $=\beta 0+\beta 1$ GCGit $+\beta 2$ NPMit $+\beta 3$ SIZEit + eit 
Model yang kedua menguji pengaruh pengungkapan tata kelola perusahaan terhadap kinerja pasar. Berikut model regresi kedua dalam penelitian ini yaitu:

\begin{tabular}{|c|c|c|}
\hline \multicolumn{3}{|l|}{ Dimana: } \\
\hline ROE & : & $\begin{array}{l}\text { Nilai rasio return on equity yang digunakan untuk } \\
\text { mengukur kinerja operasional perusahaan i pada tahun } \\
\text { t }\end{array}$ \\
\hline TOBINS & : & $\begin{array}{l}\text { Nilai rasio tobins } Q \text { yang digunakan untuk mengukur } \\
\text { kineria nasar prusahaan i nada tahun }\end{array}$ \\
\hline GCG & : & $\begin{array}{l}\text { Score penerapan rekomendasi tata kelola perusahaan i } \\
\text { pada tahun } \mathrm{t}\end{array}$ \\
\hline NPM & : & $\begin{array}{l}\text { Nilai rasio profitabilitas yang diukur menggunakan } \\
\text { nilai net profit margin }\end{array}$ \\
\hline SIZE & : & Logaritma natural dari total aset \\
\hline
\end{tabular}

Tabel 2 menunjukkan statistik deskriptif untuk setiap variabel yang digunakan dalam penelitian ini.

Tabel 2. Statistik deskriptif

\begin{tabular}{ccccccc}
\hline Variabel & Obs. & Mean & Med & Max & Min. & Std. Dev \\
\hline TOBINS Q & 120 & 2.628 & 1.534 & 23.285 & 0.422 & 3.638 \\
ROE & 120 & 0.156 & 0.108 & 1.563 & $-0,684$ & 0.321 \\
GCG & 120 & 0.627 & 0.680 & 0.960 & 0.160 & 0.198 \\
LEV & 120 & 0.413 & 0.364 & 2.899 & 0.076 & 0.314 \\
SIZE & 120 & 28.68 & 28.23 & 32.20 & 25.66 & 1.698 \\
NPM & 120 & 0.056 & 0.060 & 1.013 & -2.680 & 0.289 \\
\hline
\end{tabular}

Sumber: diolah

Uji hipotesis model 1 dan model 2 dalam penelitian ini menggunakan fixed effect model sebagai model terbaik. Ringkasan uji hipotesis terdapat dalam Tabel 3 sebagai berikut:

Tabel 3. Ringkasan Uji Hipotesis

\begin{tabular}{|c|c|c|c|c|c|c|c|c|}
\hline & \multicolumn{3}{|c|}{ Kinerja Operasi } & \multicolumn{5}{|c|}{ Kinerja Pasar } \\
\hline Var. & Coeff. & t-Stat. & Prob. & & Coeff. & t-Stat. & Prob. & \\
\hline $\mathrm{C}$ & -6.836 & -6.831 & 0.000 & $* * *$ & 56.952 & 3.186 & 0.001 & $* * *$ \\
\hline GCG & -0.163 & -2.754 & 0.003 & $* * *$ & 0.425 & 0.343 & 0.365 & \\
\hline LEV & -0.033 & -0.532 & 0.298 & & -0.489 & -0.712 & 0.239 & \\
\hline SIZE & 0.248 & 6.919 & 0.000 & $* * *$ & -1.894 & -3.018 & 0.001 & $* * *$ \\
\hline NPM & -0.297 & -3.958 & 0.000 & $* * *$ & -0.165 & -0.406 & 0.342 & \\
\hline $\mathrm{R}^{2}$ & \multicolumn{3}{|c|}{0.976} & \multicolumn{5}{|c|}{0.947} \\
\hline Adj. $\mathrm{R}^{2}$ & \multicolumn{3}{|c|}{0.967} & \multicolumn{5}{|c|}{0.927} \\
\hline F-stat. & \multicolumn{3}{|c|}{106.91} & \multicolumn{5}{|c|}{46.957} \\
\hline Prob(F-stat.) & \multicolumn{3}{|c|}{0.000} & \multicolumn{5}{|c|}{0.000} \\
\hline
\end{tabular}

Sumber: diolah 


\section{PEMBAHASAN}

Pengaruh penerapan pengungkapan tata kelola perusahaan terhadap kinerja operasional. Dalam pengujian hipotesis menunjukkan bahwa penerapan pengungkapan tata kelola perusahaan berpengaruh negatif terhadap kinerja operasional. Penelitian ini sejalan dengan (Tertius dan Christiawan, 2015) dan (Veno, 2015). Penelitian ini menunjukkan bahwa penerapan pedoman tata kelola perusahaan sesuai dengan rekomendasi dari OJK memiliki pengaruh terbalik terhadap kinerja operasional perusahaan. Penerapan prinsip tata kelola perusahaan menyebabkan manajer kurang maksimal dalam mengelola sumber daya secara efektif. Salah satu prinsip dalam pedoman tata kelola perusahaan adalah untuk memperkuat keanggotaan dan komposisi dewan komisaris (OJK, 2015). Dewan komisaris merupakan salah satu unsur yang digunakan untuk melakukan monitor kinerja manajer. Namun demikian, ukuran dewan komisaris yang besar kurang efektif dalam melakukan pengawasan terhadap kinerja manajer (Veno, 2015).

Secara umum, perusahaan di Indonesia telah menerapkan tata kelola perusahaan berdasarkan kuantitas yang dilaporkan dari segi kuantitas. Rata-rata perusahaan telah menerapkan 15 prinsip dari 25 kriteria tata kelola perusahaan dalam penelitian ini. Bahkan sebagian besar sampel perusahaan pada penelitian ini telah mengungkapkan informasi penerapan tata kelola perusahaan yang telah diterapkan pada laporan tahunan secara rinci sesuai dengan pedoman yang ada. Berdasarkan statistik deskriptif diketahui bahwa nilai rata-rata rekomendasi yang diterapkan oleh perusahaan yang diobservasi sebanyak $62.73 \%$ dari total yang seharusnya diungkapkan. Hal ini sejalan dengan penilaian yang dilakukan ACGS Indonesia pada tahun 2017 yang menyatakan bahwa penerapan praktik pengungkapan tata kelola perusahaan di Indonesia relatif membaik (Siregar, 2018). Sampel perusahaan pada dasarnya telah cukup melaksanakan rekomendasi prinsip tata kelola perusahaan yang baik, namun hal ini tidak menunjukkan peningkatan kinerja operasional pada sampel perusahaan yang memiliki rata-rata ROE sebesar 15,61\%.

Tingginya penerapan prinsip tata kelola perusahaan oleh perusahaan tidak menunjukkan kualitas kinerja operasional perusahaan menjadi semakin baik. Bahkan kinerja operasional yang ada cenderung mengalami penurunan. Berdasarkan pedoman tata kelola perusahaan sesuai dengan rekomendasi yang dibuat OJK, prinsip-prinsip yang ada cenderung menuntut manajer untuk bekerja lebih banyak demi kepentingan pemilik, namun tidak diiringi dengan peningkatan kesejahteraan manajer. Kepentingan pemegang saham dan agen kurang dapat terwujud disebabkan karena manajer tidak seutuhnya mendapatkan keuntungan yang diperoleh namun harus mengeluarkan biaya yang lebih besar (Tertius dan Christiawan, 2015).

Lima prinsip praktik tata kelola perusahaan dalam OECD (Hediono dan Prasetyaningsih, 2019), tampaknya hanya menekankan hak dari pemilik namun mengabaikan insentif bagi manajer dalam mengelola perusahaan. Penerapan prinsip pengungkapan tata kelola perusahaan tidak memberikan keuntungan secara langsung kepada manajemen, malah menambah biaya yang harus dikeluarkan oleh manajer. Penerapan tersebut menunjukkan bahwa praktik pengungkapan tata kelola perusahaan tidak mampu mengatasi masalah keagenan antara pemilik dan pengelola. Dengan 
demikian, manajer dianggap tidak bekerja secara optimal untuk menghasilkan laba yang tinggi dan dianggap tidak mampu memaksimalkan kesejahteraan pemilik modal.

Pengaruh penerapan pengungkapan tata kelola perusahaan terhadap kinerja pasar. Hasil uji hipotesis kedua menunjukkan bahwa penerapan pengungkapan tata kelola perusahaan tidak berpengaruh kinerja pasar. Hasil pengujian ini sejalan dengan (Putri et al., 2020), (Firmansyah et al., 2021), (Fatchan dan Trisnawati, 2016) namun tidak sejalan dengan (Syafitri et al., 2018) dan (Sarafina, 2017). Hasil pengujian ini mengindikasikan bahwa penerapan pengungkapan tata kelola perusahaan tidak direspon oleh investor di pasar modal. Perusahaan yang menerapkan pedoman tata kelola perusahaan tidak berhubungan dengan minat para investor untuk menanamkan modalnya. Keberhasilan manajer dalam perusahaan tidak hanya dapat menghasilkan keuntungan yang tinggi, namun manajer harus mampu meningkatkan kepercayaan di matas publik. Pengungkapan tata kelola perusahaan seyogyanya merupakan sistem yang mengontrol perusahaan untuk menciptakan nilai tambah bagi para stakeholder yang tercermin dari kinerja pasar yang optimal. Kinerja pasar yang tinggi menggambarkan keberhasilan manajer dalam meyakinkan kepercayaan pemegang saham. Namun, investor tidak mempertimbangkan pengungkapan tata kelola dalam pengambilan keputusan investasi di pasar modal (Fatchan dan Trisnawati, 2016; Putri et al., 2020; Firmansyah et al., 2021).

Idealnya, penerapan prinsip pengungkapan tata kelola perusahaan oleh perusahaan akan menciptakan citra baik perusahaan dalam mengelola modal investor. Berdasarkan uji statistik deskriptif diketahui nilai mean dari Tobins Q pada sampel dengan 120 data observasi adalah sebesar 2,6283. Hasil tersebut menunjukkan bahwa perusahaan yang nilai perusahaan dua kali lebih tinggi dari nilai sebenarnya perusahaan tersebut oleh para investor. Namun, kondisi tersebut bukan didorong akibat penerapan tata kelola perusahaan yang baik. Rata-rata pengungkapan tata kelola menunjukkan bahwa perusahaan telah memenuhi pedoman OJK sejalan dengan temuan dari (Putri et al., 2020) dan (Firmansyah et al., 2021). Meskipun perusahaan mengklaim hampir telah memenuhi penerapan tata kelola perusahaan, namun investor menilai klaim tersebut hanya dilakukan sepihak dan tidak mengurangi keberadaan informasi asimetri antara manajer dan pemegang saham (Firmansyah et al., 2021). Selain itu, investor menilai pengungkapan tata kelola perusahaan sebagaimana pedoman OJK Indonesia saat ini hanya bersifat sukarela, namun tidak terdapat adanya sanksi apabila perusahaan tidak menerapkannya.

Pedoman tata kelola sebagaimana Surat Edaran OJK No. 32 tahun 2015 yang hanya menggunakan pendekatan "comply" or "explain" hanya menciptakan ruang bagi perusahaan untuk menginterpretasikan hasil pemahamannya masing-masing (Firmansyah, 2021). Perbedaan interpretasi ini membuat pengungkapan tata kelola tidak berfungsi dengan baik karena masing-masing perusahaan dapat mendefinisikan definisi menurut pandangan pribadinya. Akibatnya, pengungkapan tata kelola perusahaan hanya memenuhi persyaratan administratif tetapi belum tercermin dalam kinerja atau aktivitasnya (Sakessia dan Firmansyah, 2020). 


\section{KESIMPULAN}

Pengungkapan tata kelola perusahaan menurunkan kinerja operasional. Bagi manajer, praktik tata kelola perusahaan tidak mampu mengatasi masalah keagenan yang ada antara agen dengan para pemilik. Seharusnya penerapan tata kelola perusahaan mendorong kinerja para manajer lebih baik dengan adanya prinsip transparansi informasi perusahaan kepada publik. Penerapan tata kelola perusahaan diduga malah menambah tugas dan kewajiban para manajer, namun tidak diikuti dengan peningkatan kesejahteraan dari para manajer. Sementara itu, pengungkapan tata kelola perusahaan tidak berkaitan dengan kinerja pasar perusahaan. Pengungkapan informasi penerapan tata kelola perusahaan masih belum berhasil implementasikan dengan baik oleh perusahaan di Indonesia dan masih bersifat administratif.

Terdapat beberapa keterbatasan dalam penelitian ini. Pertama, Pemberian skor pengungkapan tata kelola perusahaan sesuai dengan surat edaran indeks OJK yang berjumlah 25 item dilakukan dalam penelitian ini memungkinkan terdapatnya unsur subjektivitas yang tidak dapat dihindarkan. Peneliti selanjutnya dapat menambahkan variabel indikator pengungkapan tata kelola perusahaan dengan pengukuran lain seperti dengan menggunakan indeks OECD dan Asean scorecard index, atau indeks tata kelola perusahaan yang dikeluarkan oleh beberapa lembaga pemeringkatan lain untuk membandingkan hasil pengujiannya dengan penelitian ini. Kedua, sampel penelitian ini tidak dapat menggeneralisasi secara menyeluruh perusahaan di Indonesia karena hanya menggunakan data satu sektor dan hanya menggunakan data tahun 2015 s.d. 2019. Penelitian selanjutnya dapat menggunakan data dan informasi sektor lainnya sehingga hasil pengujiannya dapat dibandingkan dengan hasil penelitian ini. Selain itu, penelitian selanjutnya dapat menggunakan jangka waktu yang lebih panjang untuk mendapatkan hasil pengujian yang lebih baik.

Penelitian ini mengindikasikan bahwa Otoritas Jasa Keuangan perlu meningkatkan kualitas pedoman tata kelola perusahaan yang baik sesuai dengan kondisi saat ini. Selain itu, OJK dapat melakukan monitoring mengenai kualitas implementasi tata kelola perusahaan terbuka yang ada di Indonesia. Selain itu, investor dan calon investor dapat menggunakan hasil penelitian ini sebagai bahan pertimbangan dalam pengambilan keputusan investasi di pasar modal dengan mempertimbangkan penerapan tata kelola yang diterapkan oleh emiten di pasar modal.

\section{DAFTAR PUSTAKA}

Anggraini, J. (2010). Analisis kinerja operasional perusahaan sebelum dan sesudah right issue pada perusahaan manufaktur yang terdaftar di BEI. Skripsi: Universitas Sebelas Maret.

Ahmad, B., Siregar, H., dan Maulana, Tb. N. A. (2017). Penggunaan hedging oleh perusahaan telekomunikasi yang tercatat pada Bursa Efek Indonesia. Jurnal Aplikasi Bisnis dan Manajemen, 3(3), 435-446.

Akana, D. R. (2017). Pengaruh penerapan prinsip-prinsip good corporate governance terhadap kinerja keuangan BPJS Ketenagakerjaan di Kota Pekanbaru. Skripsi : Universitas Islam Negeri Sultan Syarif Kasim Riau. 
Al-Matari, E. M., Al-Swidi, A. K., and Fadzil, F. H. (2014). The measurement of firm perfomance's dimensions. Asian Journal Of Finance \& Accounting, 6(1), 24-49.

Azis, A. and Hartono, U. (2017). Corporate governance, struktur modal, leverage dan kinerja keuangan : Studi pada perusahaan pertambangan Indonesia. Jurnal Ilmu Manajemen, 5(3), $1-13$.

Az'ari, N. A., Irfan, M., dan Nurfaidah (2020). Pengaruh good corporate governance terhadap kinerja keuangan perusahaan perbankan yang terdaftar di BEI. Trilogi Accounting And Business Research, 1(1), 100-122.

Darwis, H. (2012). Manajemen laba terhadap nilai perusahaan dengan corporate governance sebagai pemoderasi. Jurnal Keuangan Dan Perbankan. 16(1). 45 - 55.

Dewi, A. S., Sari, D., dan Abaharis, H. (2018). Pengaruh karakteristik dewan komisaris terhadap kinerja perusahaan manufaktur di Bursa Efek Indonesia. Jurnal Benefita, 3(3), 445-454.

Dwiridotjahjono, J. (2010). Penerapan good corporate governance : manfaat dan tantangan serta kesempatan bagi perusahaan publik di Indonesia. Jurnal Administrasi Bisnis, 5(2), 101-112.

Dzahabiyya, J., Jhoansyah, D., dan Danial, R. D. M. (2020). Analisis nilai perusahaan dengan model rasio tobin's Q. Jurnal Riset Akuntansi Dan Keuangan Dewantara, 4(1), 46-55.

Effendi, E. S. dan Hermanto, S. B. (2017). Pengaruh rasio keuangan dan volume perdagangan terhadap return saham. Jurnal Ilmu Dan Riset Akuntansi, 6(11), 1-21.

Fadillah, A. R. (2017). Analisis pengaruh dewan komisaris independen, kepemilikan manajerial dan kepemilikan institusional terhadap kinerja perusahaan yang terdaftar di LQ45. Jurnal Akuntansi, 12(1), 1-16.

Fatchan, I. N., dan Trisnawati, R. (2016). Pengaruh good corporate governance pada hubungan antara sustainability report dan nilai perusahaan (studi empiris perusahaan go public di Indonesia periode 2014-2015). Riset Akuntansi dan Keuangan Indonesia, 1(1), 25-34.

Ferdiani, K.R. (2019). Pengertian investasi, jenis, dan manfaatnya. diakses dari : https://www.modalrakyat.id/blog/pengertian-investasi-jenis-dan-manfaatnya.

Febrianto, A. (2016). Analisis pengukuran kinerja perusahaan dengan metode pendekatan balance scorecard. Jurnal Ilmu Administrasi Bisnis, 5(3), 1-20.

Firmansyah, A., and Ardi, A. K. (2020). Related party transactions, supply chain and cost management on firm's value: evidence from Indonesia. International Journal of Supply Chain Management, 9(3), 1201-1209.

Firmansyah, A., and Purnama E. D. B. (2020). Do derivatives instruments ownership decrease firm value in indonesia? Riset Akuntansi dan Keuangan Indonesia, 5 (1), 19.

Firmansyah, A., Husna, M. C., and Putri, M. A. (2021). Corporate social responsibility disclosure, corporate governance disclosure, and firm value in Indonesia chemical, plastic, and packaging sub-sector companies. Accounting Analysis Journal, 10(1), 9 -17 .

Hadiyanti, H. (2013). Sejarah Kasus Enron. Diakses dari : https://hafikahadiyanti.wordpress.com/2013/09/10/sejarah-kasus-enron/. 
Haryono, U. and Paminto, A. (2015). Corporate Governance and Firm Value: The mediating effect of financial performance and firm risk. European Journal of Business and Mangement, 7(35), 18-24.

Hediono, B. P dan Prasetyaningsih, I. (2019). Pengaruh Implementasi Good Corporate Governance Terhadap Kinerja Keuangan Perusahaan. Jurnal Riset Manajemen Dan Bisnis, 14(1), 47 - 58.

Hidayat, W. W. (2019). Pengaruh ukuran perusahaan, return on equity dan leverage terhadap nilai perusahaan pada perusahaan manufaktur di Indonesia. Forum Ekonomi, 21(1), 67-75.

Ibrahim, A. (2016). Analisis implementasi manajemen kualitas dari kinerja operasional pada industri ekstraktif di Sulawesi Utara. Jurnal Ekonomi, Manajemen, Bisnis, Dan Akuntansi, 4(2), 859 - 869.

Ichsan, R. (2013). Teori Keagenan (Agency Theory). Diakses dari : https://bungrandhy.wordpress.com/2013/01/12/teori-keagenan-agency-theory/.

Irawan, F., and Turwanto. (2020). The Effect of Tax Avoidance on Firm Value with Tax Risk as Moderating Variable.Test Engineering and Management, 83: 9696 - 9707.

Jensen, M. C., and Meckling, W. H. (1976). Theory of the firm: managerial behavior, agency costs and ownership structure. Journal of Financial Economics, 3(4), 305360.

Kaban, A., Sihombing, M., dan Tarigan, U. (2017). Analisis prinsip-prinsip good corporate governance pada perusahaan pembiayaan. Jurnal Administrasi Publik, 7(1), 1-16.

Karina, D. R. M., dan Setiadi, I. (2020). Pengaruh CSR terhadap nilai perusahaan dengan GCG sebagai pemoderasi. JRAMB, 6(1), 37-49.

Kholis, N., Sumarmawati, E. D., and Mutmainah, H. (2018). Factors that influence value of the company faktorfaktor yang mempengaruhi nilai perusahaan. Jurnal Analisis Bisnis Ekonomi, 16(1), 19-25.

Kurniasari, V. dan Memarista, G. (2017). Analisis kinerja perusahaan menggunakan metode balance scorecard. Agora, 5(1), 1-7.

Lestari, H.S. (2017). Pengaruh intellectual capital terhadap kinerja perusahaan di Indonesia. Jurnal Manajemen, 21(3), 491-509.

Lestari, A., Rizan, M., dan Amali, L. M. (2018). Pengaruh modal kerja terhadap net profit margin pada perusahaan real estate yang terdaftar di BEI. Jurnal Ilmiah Manajemen dan Bisnis, 1(1), 86-95.

Lisa, O (2012). Asimetri informasi dan manajemen laba : Suatu tinjauan dalam hubungan keagenan. Jurnal WIGA. 2 (1). 42-29.

Lubis, I. L., Sinaga, B. M., dan Sasongko, H. (2017). Pengaruh profitabilitas, sruktur modal, dan likuiditas terhadap nilai perusahaan. Jurnal Aplikasi Bisnis dan Manajemen, 3(3), 458-465.

Lukman, I. (2014). Pengaruh ukuran perusahaan, kesempatan bertumbuh, dan leverage terhadap keresponan laba pada perusahaan properti dan real estate yang terdaftar di BEI tahun 2009 - 2012. Skripsi : Universitas Negeri Padang.

Maretha, R. A. (2016). Pengaruh ukuran perusahaan dan debt to equity ratio terhadap nilai perusahaan (Studi pada perusahaan manufaktur sektor industri dasar dan kimia yang terdaftar di BEI). Skripsi : Universitas Pasundan Bandung. 
Masitoh, N. S dan Hidayah, N. (2018). Pengaruh penerapan good corporate governance terhadap kinerja perusahaan. Jurnal Tekun, 1(1), 49-59.

Mujiati, I. R., Rosdiana, Y., \& Lestari, R. (2016). Pengaruh pengungkapan good corporate governance terhadap kinerja keuangan perusahaan. Prosiding Akuntansi, 2(1), 43 49.

Natalia, M., Gunawan, Y., dan Carolina, V. (2016). Pengaruh pengungkapan tanggung jawab sosial perusahaan terhadap kinerja pasar dengan moderasi efektifitas dewan komisaris dan independensi dewan komisaris. Jurnal Akuntansi, 8(1), 45 - 64.

Naufal, A. A. (2018). Pengaruh Kualitas Produk terhadap Kinerja Operasional Industri Busana Muslim di Kota Bandung. Skripsi : Universitas Katolik Parahyangan.

Novianti, T, and, Firmansyah, A. (2020). The effect of tax risk, hedging, income smoothing, and cash flows volatility on firm value. Test Engineering and Management, 83, 9675 - 9686

Oktavia. (2011). Perataan Laba dan Kaitannya Dengan Nilai Perusahaan. Jurnal Akuntansi, 11(2), 431-450.

Otoritas Jasa Keuangan. Surat Edaran Otoritas Jasa Keuangan Nomor 32/SEOJK.04/2015. Pedoman Tata Kelola Perusahaan Terbuka.

Pratiwi, R. A. (2019). Pengaruh pertumbuhan perusahaan, profitabilitas, struktur modal, kepemilikan manajerial dan kebijakan dividen terhadap nilai perusahaan. Skripsi : Universitas Muhammadiyah Surakarta.

Putri, K. R dan Muid, D (2017). Pengaruh good corporate governance terhadap kinerja perusahaan. Jurnal Akuntansi, 6(3), 1-9.

Putri, M. M., Firmansyah, A., and Labadia, D. (2020). Corporate social responsibility disclosure, good corporate governance, firm value: evidence from Indonesia's Food And Beverage Companies. The Accounting Journal of Binaniaga, 5(2), 113-122.

Rahayu, M. dan Sari, B. (2018). Faktor-Faktor yang Memengaruhi Nilai Perusahaan. Ikraith-Humaniora, 2(2), 69-76.

Rudangga, I.G.N dan Sudiarta, G. M. (2016). Pengaruh ukuran perusahaan, leverage, dan profitabilitas terhadap nilai perusahaan. E-Jurnal Manajemen, 5(2), 4394 - 4422

Sakessia and Firmansyah, A. (2020). The role of corporate governance on earnings quality from positive accounting theory framework. International Journal of Scientific \& Technology Research, 9(1), 808-820.

Salim, F. S. dan Simatupang, A. (2016). Kinerja Keuangan dan Kondisi Ekonomi Makro Terhadap Pengembalian Saham Perusahaan Property dan Real Estateyang Terdaftar di Bursa Efek Indonesia Periode Tahun 2011-2014. Jurnal Administrasi Kantor, $4(1), 47-67$.

Sambelay, J. J., Van Rate, P., dan Baramuli, D. N. (2017). Analisis pengaruh profitabilitas terhadap harga saham pada perusahaan yang terdaftar di LQ45 periode 2012-2016. Jurnal Riset Ekonomi, Manajemen, Bisnis, Dan Akuntansi, 5(2), 753-761.

Sambora, M. N., Handayani, S. R., dan Rahayu, S. M. (2014). Pengaruh leverage dan profitabilitas terhadap nilai perusahaan. Jurnal Administrasi Bisnis, 8(1), 1-10.

Sarafina, S. dan Saifi, M. (2017). Pengaruh Pengungkapan tata kelola perusahaan terhadap kinerja keuangan dan nilai perusahaan. Jurnal Admnintrasi Bisnis, 50(3), 108-117. 
Setiawan, N. H. (2017). Perbedaan Kinerja Keuangan dan Kinerja Pasar sebelum dan setelah Penerapan ESOP pada Perusahaan yang tercatat di BEI. Skripsi: STIE Perbanas Surabaya.

Sianggono, A. dan Mustamu, R. H. (2018). Penerapan prinsip-prinsip pengungkapan tata kelola perusahaan pada perusahaan keluarga dalam industri mebel. Agora, 6(1), 1-6.

Sintyana, I dan Artini, L G. (2019). Pengaruh profitabilitas, struktur modal, ukuran perusahaan dan kebijakan dividen terhadap nilai perusahaan. Jurnal Manajemen, 8(2), 7717 - 7745.

Siregar, R. (2016). Pengaruh leverage dan profitabilitas terhadap nilai perusahaan pada PT Unilever Indonesia, Tbk. yang terdaftar di BEI. Jurnal Financial, 2(1), 1-6.

Situmorang, C. H. dan Sminajuntak, A. (2019). Pengaruh good corporate governance terhadap kinerja keuangan perusahaan perbankan yang terdaftar di BEI. Jurnal Akuntansi dan Bisnis. 5(2), 160-169.

Sodikin, I. Wisnubroto, P., dan Ayunin, N. M. (2017). Pengukuran kinerja perusahaan menggunakan strategic management analysis and reporting technique (SMART) system di PT Telkom Witel Magelang. Industrial Engineering Journal of The University of Sarjanawiyata Tamansiswa, 1(1), 9-16.

Suharyati. (2019). Penerapan good corporate governance terhadap kinerja perusahaan pada perusahaan manufaktur yang terdaftar pada Bursa Efek Indonesia tahun 2013-2016. Skripsi : STIE Mahardika Surabaya.

Suroto. (2018). Analisis Faktor-Faktor yang memengaruhi nilai perusahaan studi empiris pada perusahaan LQ-45. Serat Acitya-Jurnal Ilmiah UNTAG Semarang,7(2), 97101.

Suryahadi, A. (2020). Sektor barang konsumsi jadi jawara sejak awal tahun. Diakses dari : $\quad$ https://investasi.kontan.co.id/news/sektor-barang-konsumsi-jadi-jawara-sejakawal-tahun-simak-rekomendasi-analis-berikut-1.

Susilo, M. B., Fuad (2018). Pengaruh Pengungkapan tata kelola perusahaan terhadap Kinerja Keuangan Perusahaan pada Perusahaan Manufaktur yang Terdaftar di Bursa Efek Indonesia tahun 2013-2016. Jurnal Akuntansi Dipenogoro, 7(4), 1-11.

Syafitri, T., Nuzula, N. F., dan Nurlaily, F. (2018). Pengaruh Pengungkapan tata kelola perusahaan terhadap nilai perusahaan. Jurnal Administrasi Bisnis, 56(1), 118-126.

Tertius, M. A., dan Christiawan, Y. J. (2015). Pengaruh Pengungkapan tata kelola perusahaan terhadap kinerja perusahaan pada sektor keuangan. Business Accounting Review, 3(1), 223-232.

Veno, A. (2015). Pengaruh Pengungkapan tata kelola perusahaan terhadap Kinerja Perusahaan pada Perusahaan Manufaktur Go Public. Benefit Jurnal Manajemen dan Bisnis, 19(1), 95-112.

Wiyarsi, R. B. (2012). Pengaruh corporate governance terhadap manajemen laba. Skripsi: Universitas Muhammadiyah Surakarta.

http://kumpulanstudi-aspirasi.com/hukum/skandal-akuntansi-terbesar-enron-2001/ diakses tanggal 16 Maret 2021. 